\title{
Loss of a Legend: Remembering Robert M. Kacmarek
}

\section{Dean R Hess}

On April 1, 2021, we lost our longest serving Editorial Board member, Robert M Kacmarek PhD RRT FAARC (Fig. 1). Bob joined the Editorial Board in 1985. Over the subsequent years, Bob contributed to the evolution of the Journal in many meaningful ways, as author, reviewer, and Editorial Board member. His tenure on the Editorial Board eclipsed 5 editors: Philip Kittredge, Pat Brougher, David Pierson, Dean Hess, and Richard Branson. He authored or co-authored 113 papers in the Journal between 1982 and 2021. ${ }^{1-113}$

Bob's first publications in the Journal were a 3-part series on the technical aspects of PEEP. ${ }^{1-3}$ A co-author on those papers was Barry Shapiro, a physician and long-term supporter of the respiratory care profession until his death in 2008. Bob had a career-long interest in PEEP, and that had its genesis in these papers. Of note, in the early 1980 s the use of PEEP was not common, and its use was controversial. It was a big deal to set PEEP on the ventilator back then. For respiratory therapists and critical care physicians practicing today, it is unthinkable that the ventilator could be set without PEEP, but it was common at that time. These papers on PEEP published in 1982 are classics and of interest even today, almost 40 years later.

The first ReSPIRATORY CARE Journal Conference was in 1982. ${ }^{114}$ Three years later, Bob presented 2 lectures at the 1985 conference on the topic of neonatal respiratory care. ${ }^{4,5}$ He participated in 17 Journal Conferences since 1985 (Fig. 2). It is noteworthy that Bob participated in the 1986 Journal Conference on mechanical ventilation ${ }^{7}$

Dr Hess is affiliated with the Respiratory Care Department, Massachusetts General Hospital, and with Northeastern University, Boston, Massachusetts.

Dr Hess is Managing Editor for Respiratory CARE.

Dr Hess has disclosed relationships with Ventec Life Systems, Daedalus Enterprises, Jones and Bartlett, McGraw-Hill, and UpToDate.

Correspondence: Dean R Hess PhD RRT FAARC.E-mail: dhess@aarc.org.

DOI: $10.4187 /$ respcare.09221

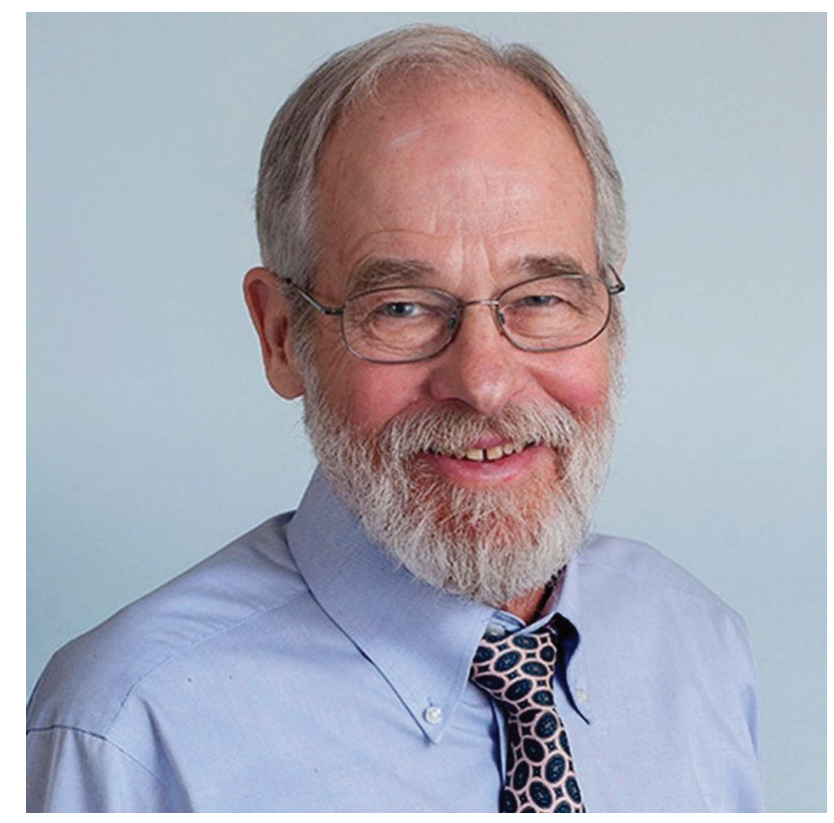

Fig. 1. Robert M Kacmarek PhD RRT FAARC. February 5, 1949 April 1, 2021.

and the 1987 Journal Conference on PEEP. ${ }^{9}$ Bob's coauthor on the PEEP paper $^{9}$ was the late Thomas L. Petty. Mechanical ventilation and PEEP are the subject areas around which Bob built his career.

Although Bob authored many papers in the Journal related to invasive mechanical ventilation, he was not monolithic. He also wrote papers related to monitoring, ${ }^{14}$ noninvasive ventilation, ${ }^{13,14,39,40,46,50,58,63,64,74,77,79,102,109,112}$ inhaled nitric oxide, ${ }^{35,37,42}$ and aerosol therapy. ${ }^{15,22,27,90}$ Bob was one of the first to draw attention to the potential hazards to respiratory therapists related to secondhand aerosol inhalation. ${ }^{15}$ Typical of Bob, not only did he identify a problem, but he also offered the solution. ${ }^{15}$ His papers addressed many aspects of the professional practice of respiratory care. ${ }^{1,4,26,60,62,65-68,73,76,103}$

Bob presented scores of lectures as an invited speaker at the annual congress of the American Association for Respiratory Care. He is one of only 4 persons to present both the Philip Kittredge Memorial Lecture (1991; it was called the Program Committee Lecture at that time) and 


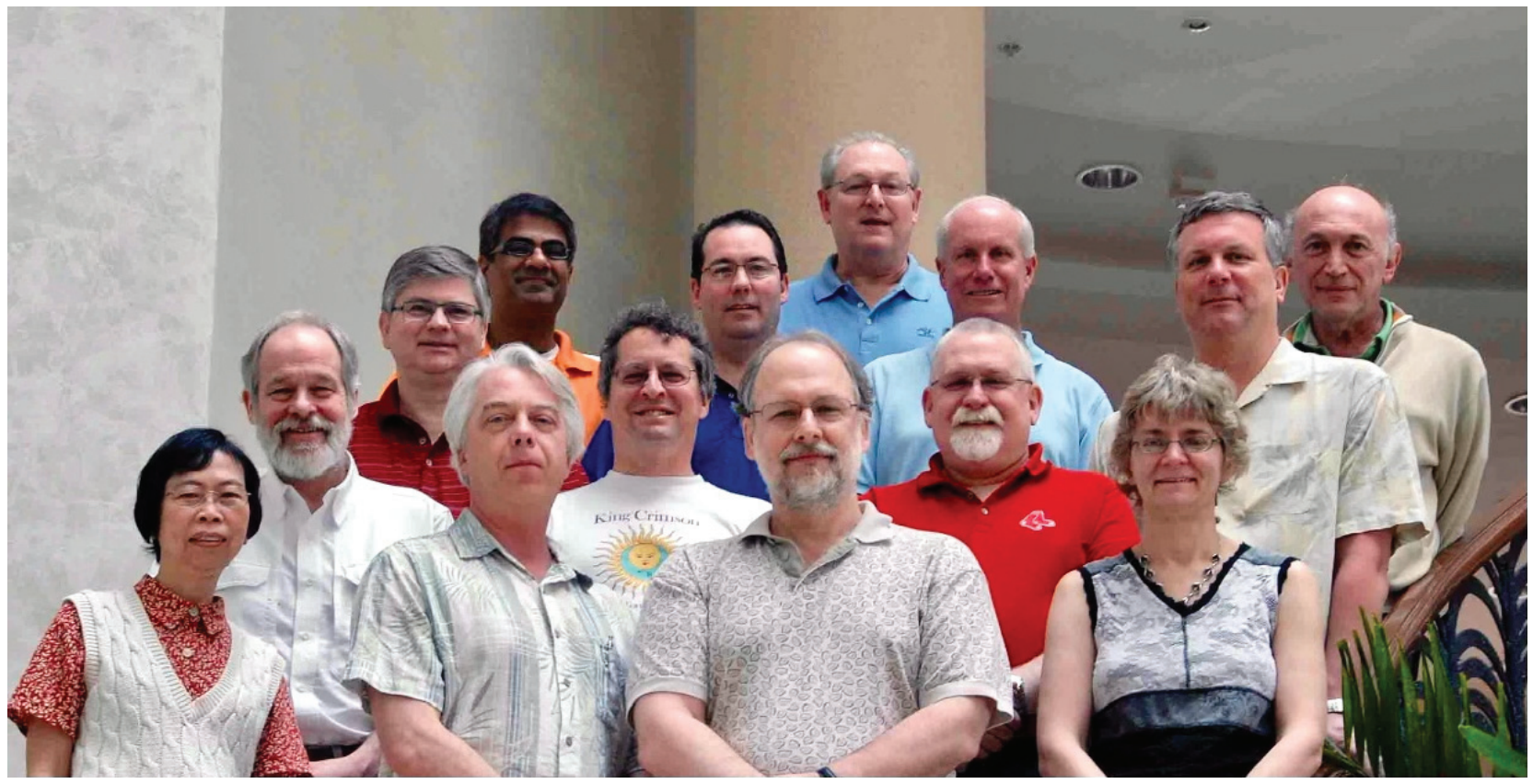

Fig. 2. Respiratory Care Journal Conference. March 19-21, 2010. Bob Kacmarek is seen in second row, far left.

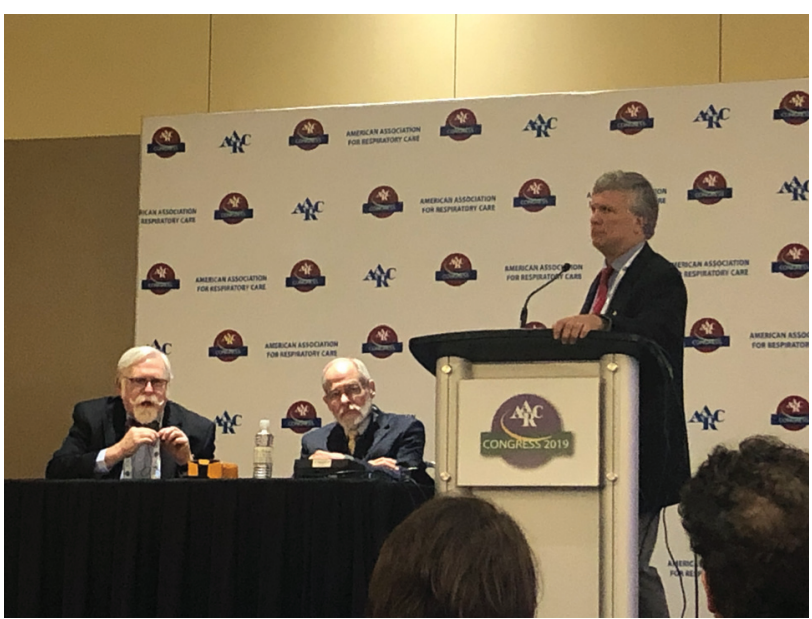

Fig. 3. AARC Congress. November 11, 2019. Bob Kacmarek (center) with Managing Editor Dean Hess (left) and Editor-in-Chief Richard Branson (at podium). Photograph courtesy of Carolyn J. LaVita.

the Donald F. Egan Memorial Lecture (2010). The title of the first was "Respiratory Care Practitioner: Carpe Diem!," ${ }^{26}$ in which Bob challenged the profession to "become true professionals-not factory workers working in hospitals." Indeed, Bob followed his own challenge and built the respiratory care department at Massachusetts General Hospital in Boston into the preeminent department in the world, where respiratory therapists are clinical leaders at the bedside and respected members of the health care team. The
"Carpe Diem" lecture also illustrated Bob's humility. He admitted to not knowing the meaning of the term and sending his wife to the library to investigate its meaning. The title of the Egan Lecture was "The Mechanical Ventilator: Past, Present, and Future"; ${ }^{69}$ it might be the best history of mechanical ventilation written to date.

Bob's passion for the respiratory care profession is best illustrated by his leadership on the AARC task force to identify new roles and responsibilities of respiratory therapists in the year 2015 and beyond. ${ }^{65-68,73,76}$ One of the recommendations of this task force was to require a baccalaureate degree for entry into the profession, and Bob became a fierce advocate for that standard. Bob possessed the courage of his convictions and fought hard, without apology for issues that he thought important.

The OPEN Forum is an important part of the annual congress of the American Association for Respiratory Care, where original research related to respiratory care is presented by respiratory therapists and others. ${ }^{115}$ Bob first presented at the Open Forum in 1980 and contributed 74 Open Forum abstracts. He was a faithful and critical reviewer of submitted abstracts. The highlight of the careers of many young respiratory therapists was the opportunity to present an OPEN Forum abstract in a session chaired by Bob.

In addition to writing, one of Bob's greatest loves was lecturing. He provided thousands of lectures on numerous topics locally, nationally, and internationally. He was a featured speaker for many professional societies, 


\section{REMEMBERING Robert M. KACMAREK}

including scores of lectures at the annual congress of the AARC (Fig. 3). Bob lectured on 6 of the 7 continents and, for decades, was a worldwide ambassador for the respiratory care profession. He was always the strongest person in the room, and his presence was bigger than any room, regardless of the size. Bob Kacmarek had a profound impact on the respiratory care profession, and his influence is enduring. He will not be forgotten.

\section{REFERENCES}

1. Kacmarek RM, Dimas S, Reynolds J. Technical aspects of positive end-expiratory pressure (PEEP): part III. PEEP with spontaneous ventilation. Respir Care 1982;27(12):1505-1518.

2. Kacmarek RM, Dimas S, Reynolds J, Shapiro BA. Technical aspects of positive end-expiratory pressure (PEEP): part II. PEEP with positive-pressure ventilation. Respir Care 1982;27(12):1490-1504.

3. Kacmarek RM, Dimas S, Reynolds J, Shapiro BA. Technical aspects of positive end-expiratory pressure (PEEP): part I. Physics of PEEP devices. Respir Care 1982;27(12):1478-1489.

4. Kacmarek RM. The present and future roles of the perinatal respiratory care practitioner. Respir Care 1986;31(6):516-523.

5. Kacmarek RM, Spearman CB. Equipment used for ventilatory support in the home. Respir Care 1986;31(4):311-328.

6. Kacmarek RM, Thompson JE. Respiratory care of the ventilatorassisted infant in the home. Respir Care 1986;31(7):605-614.

7. Kacmarek RM, Venegas J. Mechanical ventilatory rates and tidal volumes. Respir Care 1987;32(6):466-478.

8. Kacmarek RM. The role of pressure support ventilation in reducing work of breathing. Respir Care 1988;33(2):99-120.

9. Kacmarek RM, Petty TL. Historical development of positive end-expiratory pressure (PEEP). Respir Care 1988;33(6):422-433.

10. Pierson DJ, Kacmarek RM. Positive end-expiratory pressure - state of the art after 20 years. Respir Care 1988;33(6):419-421.

11. Kacmarek RM. Pressure support in perspective. Respir Care 1989;34 (2):136-138.

12. Kacmarek RM, Cycyk-Chapman MC, Young-Palazzo PJ, Romagnoli DM. Determination of maximal inspiratory pressure: a clinical study and literature review. Respir Care 1989;34 (10):868-878.

13. Kacmarek RM. Noninvasive monitoring in respiratory care: conference summary. Respir Care 1990;35(7):740-746.

14. Kacmarek RM. Noninvasive monitoring of respiratory function outside of the hospital. Respir Care 1990;35(7):719-727.

15. Kacmarek RM. Ribavirin and pentamidine aerosols: caregiver beware! Respir Care 1990;35(11):1034-1036.

16. Kacmarek RM, Hess D. Pressure-controlled inverse-ratio ventilation: panacea or auto-PEEP? Respir Care 1990;35(10):945-948.

17. Kacmarek RM, Pierson DJ. World Congress on home care. Respir Care 1990;35(1):29-36.

18. Kacmarek RM, Stanek KS, McMahon KM, Wilson RS. Imposed work of breathing during synchronized intermittent mandatory ventilation provided by five home care ventilators. Respir Care 1990;35 (5):405-414.

19. Curran JF, Stanek KS, Kacmarek RM. Portable airway-suction systems: a comparison of performance. Respir Care 1991;36(4):259266.

20. Hirsch C, Kacmarek RM, Stanek K. Work of breathing during CPAP and PSV imposed by the new generation mechanical ventilators: a lung model study. Respir Care 1991;36(8):815-828.
21. Kacmarek RM, Foley K, Cheever P, Romagnoli D. Determination of ventilatory reserve in mechanically ventilated patients: a comparison of techniques. Respir Care 1991;36(10):1085-1092.

22. Kacmarek RM, Hess D. The interface between patient and aerosol generator. Respir Care 1991;36(9):952-976.

23. Kacmarek RM, Shimada Y, Ohmura A, Takezawa J, Tokioka A, Kimura T, et al. The second Nagoya conference: triggering and optimizing mechanical ventilatory assist. Respir Care 1991;36(1):45-51.

24. Kacmarek RM. Essential gas delivery features of mechanical ventilators. Respir Care 1992;37(9):1045-1055.

25. Kacmarek RM. The role of the respiratory therapist in emergency care. Respir Care 1992;37(6):523-530.

26. Kacmarek RM. Respiratory care practitioner: carpe diem! Respir Care 1992;37(3):264-269.

27. Kacmarek RM, Kratohvil J. Evaluation of a double-enclosure double-vacuum unit scavenging system for ribavirin administration. Respir Care 1992;37(1):37-45.

28. Hess D, Kacmarek RM. Techniques and devices for monitoring oxygenation. Respir Care 1993;38(6):646-671.

29. Kacmarek RM, Hickling KG. Permissive hypercapnia. Respir Care 1993;38(4):373-387.

30. Sullivan LM, Kacmarek RM. Arrest following a prolonged course of periodic coughing and fever in a child. Respir Care 1993;38 (10):1103-1105.

31. Kacmarek KM, Stoller JK. Controversies in home respiratory care: proceedings of a conference held Oct 29-31, 1993 in St Petersburg Beach, Florida: part 1. Respir Care 1994;39(4):291-400.

32. Kacmarek RM. Home mechanical ventilatory assistance for infants. Respir Care 1994;39(5):550-561.

33. Kacmarek RM, Hess D. Routine measurement of work of breathing: is it necessary? Respir Care 1994;39(9):881-882.

34. Bernard GR, Branson RD, Brougher P, Dellinger RP, DeVries D, East TD, et al. Consensus Conference: assessing innovations in mechanical ventilatory support. Respir Care 1995;40(9):928-932.

35. Hess D, Kacmarek RM, Ritz R, Bigatello LM, Hurford WE. Inhaled nitric oxide delivery systems: a role for respiratory therapists. Respir Care 1995;40(7):702-705.

36. Kacmarek RM. Introducing new mechanical ventilation technology: the hospital perspective. Respir Care 1995;40(9):947-951.

37. Hess D, Bigatello L, Kacmarek RM, Ritz R, Head CA, Hurford WE. Use of inhaled nitric oxide in patients with acute respiratory distress syndrome. Respir Care 1996;41(5):424-446.

38. Kacmarek RM. Conference summary - mechanical ventilation: ventilatory techniques, pharmacology, \& patient management strategies. Respir Care 1996;41(5):466-472.

39. Bach JR, Brougher P, Hess DR, Hill NS, Kacmarek RM, Kreimer D, et al. Consensus conference: noninvasive positive pressure ventilation. Respir Care 1997;42(4):364-369.

40. Kacmarek RM. Characteristics of pressure-targeted ventilators used for noninvasive positive pressure ventilation. Respir Care 1997;42 (4):380-388.

41. Kacmarek RM. Points of view. Lung protective ventilatory strategies for ARDS - the data are convincing! Respir Care 1998;43(9):724-727.

42. Fujino Y, Kacmarek RM, Hess DR. Nitric oxide delivery during highfrequency oscillatory ventilation. Respir Care 2000;45(9):1097-1104.

43. Kacmarek RM. Central oxygen delivery systems: a disaster waiting to happen? Respir Care 2000;45(3):299.

44. Kacmarek RM. Delivery systems for long-term oxygen therapy. Respir Care 2000;45(1):84-92.

45. Williams P, Muelver M, Kratohvil J, Ritz R, Hess DR, Kacmarek RM. Pressure support and pressure assist/control: are there differences? An evaluation of the newest intensive care unit ventilators [corrected] [published erratum appears in Respir Care 2000;45 (12):1547]. Respir Care 2000;45(10):1169-1181. 


\section{REMEMBERING RoBERT M. KACMAREK}

46. Chatmongkolchart S, Kacmarek RM, Hess DR. Heliox delivery with noninvasive positive pressure ventilation: a laboratory study. Respir Care 2001;46(3):248-254.

47. Chatmongkolchart S, Williams P, Hess DR, Kacmarek RM. Evaluation of inspiratory rise time and inspiration termination criteria in new-generation mechanical ventilators: a lung model study. Respir Care 2001;46(7):666-677.

48. Kacmarek RM. Complications of tracheal gas insufflation. Respir Care 2001;46(2):167-176.

49. Kacmarek RM. Ventilatory adjuncts. Respir Care 2002;47(3):319330.

50. Kacmarek RM. Noninvasive positive-pressure ventilation: the little things do make the difference! Respir Care 2003;48(10):919-921.

51. Schwartz AR, Kacmarek RM, Hess DR. Factors affecting oxygen delivery with bi-level positive airway pressure. Respir Care 2004;49 (3):270-275.

52. El Masry A, Williams PF, Chipman DW, Kratohvil JP, Kacmarek RM. The impact of closed endotracheal suctioning systems on mechanical ventilator performance. Respir Care 2005;50(3):345-353.

53. Kacmarek RM. Lung protection: the cost in some is increased work of breathing. Is it too high? Respir Care 2005;50(12):1614-1616.

54. Caramez MP, Schettino G, Suchodolski K, Nishida T, Harris RS, Malhotra A, et al. The impact of endotracheal suctioning on gas exchange and hemodynamics during lung-protective ventilation in acute respiratory distress syndrome. Respir Care 2006;51(5):497-502.

55. Girgis K, Hamed H, Khater Y, Kacmarek RM. A decremental PEEP trial identifies the PEEP level that maintains oxygenation after lung recruitment. Respir Care 2006;51(10):1132-1139.

56. Kacmarek RM. NPPV in acute respiratory failure: is it time to reconsider where it may be applied? Respir Care 2006;51(11):1226-1227.

57. Chipman DW, Caramez MP, Miyoshi E, Kratohvil JP, Kacmarek RM. Performance comparison of 15 transport ventilators. Respir Care 2007;52(6):740-751.

58. Kacmarek RM. Noninvasive positive-pressure ventilation in postoperative hypoxemic respiratory failure-with a helmet? Respir Care 2007;52(11):1451-1453.

59. Kacmarek RM, Kallet RH. Respiratory controversies in the critical care setting: should recruitment maneuvers be used in the management of ALI and ARDS? Respir Care 2007;52(5):622-631.

60. Kaynar AM, Mathew JJ, Hudlin MM, Gingras DJ, Ritz RH, Jackson MR, et al. Attitudes of respiratory therapists and nurses about measures to prevent ventilator-associated pneumonia: a multicenter, crosssectional survey study. Respir Care 2007;52(12):1687-1694.

61. Steinberg KP, Kacmarek RM. Respiratory controversies in the critical care setting. Should tidal volume be $6 \mathrm{~mL} / \mathrm{kg}$ predicted body weight in virtually all patients with acute respiratory failure? Respir Care 2007;52(5):556-564

62. Prodhan P, Dela Rosa RS, Shubina M, Haver KE, Matthews BD, Buck S, et al. Wheeze detection in the pediatric intensive care unit: comparison among physician, nurses, respiratory therapists, and a computerized respiratory sound monitor. Respir Care 2008;53 (10):1304-1309.

63. Epstein SK, Kacmarek RM. Noninvasive ventilation in acute care: controversies and emerging concepts. Foreword. Respir Care 2009;54(1):38-39.

64. Kacmarek RM. Should noninvasive ventilation be used with the donot-intubate patient? Respir Care 2009;54(2):223-229.

65. Kacmarek RM, Durbin CG, Barnes TA, Kageler WV, Walton JR, O'Neil EH. Creating a vision for respiratory care in 2015 and beyond. Respir Care 2009;54(3):375-389.

66. Barnes TA, Gale DD, Kacmarek RM, Kageler WV. Competencies needed by graduate respiratory therapists in 2015 and beyond. Respir Care 2010;55(5):601-616.
67. Barnes TA, Kacmarek RM, Durbin CG, Jr. Survey of respiratory therapy education program directors in the United States. Respir Care 2011;56(12):1906-1915.

68. Barnes TA, Kacmarek RM, Kageler WV, Morris MJ, Durbin CG, Jr. Transitioning the respiratory therapy workforce for 2015 and beyond. Respir Care 2011;56(5):681-690.

69. Kacmarek RM. The mechanical ventilator: past, present, and future. Respir Care 2011;56(8):1170-1180.

70. Kacmarek RM. Proportional assist ventilation and neurally adjusted ventilatory assist. Respir Care 2011;56(2):140-148.

71. Marchese AD, Sulemanji D, Chipman D, Villar J, Kacmarek RM. Performance of current intensive care unit ventilators during pressure and volume ventilation. Respir Care 2011;56(7):928-940.

72. Villar J, Perez-Mendez L, Basaldua S, Blanco J, Aguilar G, Toral D, et al. A risk tertiles model for predicting mortality in patients with acute respiratory distress syndrome: age, plateau pressure, and $\mathrm{PaO}_{2} /$ $\mathrm{FIO}_{2}$ at ARDS onset can predict mortality. Respir Care 2011;56 (4):420-428.

73. Kacmarek RM, Barnes TA, Durbin CG, Jr. Survey of directors of respiratory therapy departments regarding the future education and credentialing of respiratory care students and staff. Respir Care 2012;57 (5):710-720.

74. Kacmarek RM, Villar J. Acute application of noninvasive ventilation outside the ICU: when is it safe? Respir Care 2012;57(5):815-816.

75. Brusasco C, Corradi F, Vargas M, Bona M, Bruno F, Marsili M, et al. In vitro evaluation of heat and moisture exchangers designed for spontaneously breathing tracheostomized patients. Respir Care 2013;58(11):1878-1885.

76. Kacmarek RM. Mechanical ventilation competencies of the respiratory therapist in 2015 and beyond. Respir Care 2013;58(6):10871096.

77. Oto J, Chenelle CT, Marchese AD, Kacmarek RM. A comparison of leak compensation in acute care ventilators during noninvasive and invasive ventilation: a lung model study. Respir Care 2013;58 (12):2027-2037.

78. Fisher DF, Chenelle CT, Marchese AD, Kratohvil JP, Kacmarek RM. Comparison of commercial and noncommercial endotracheal tube-securing devices. Respir Care 2014;59(9):1315-1323.

79. Oto J, Chenelle CT, Marchese AD, Kacmarek RM. A comparison of leak compensation during pediatric noninvasive ventilation: a lung model study. Respir Care 2014;59(2):241-251.

80. Oto J, Chenelle CT, Su Z, Sun MQ, Jiang Y, Kacmarek RM. Ventilation efficacy of video-laryngoscopes equipped with a ventilation feature. Respir Care 2014;59(11):1636-1642.

81. Sulemanji DS, Bao F, Jiang Y, Kacmarek RM. A unidirectional breathing pattern improves breathing efficiency in subjects with severe COPD. Respir Care 2014;59(10):1487-1493.

82. Vargas M, Servillo G, Tessitore G, Aloj F, Brunetti I, Arditi E, et al. Double lumen endotracheal tube for percutaneous tracheostomy. Respir Care 2014;59(11):1652-1659.

83. Brusasco C, Corradi F, De Ferrari A, Ball L, Kacmarek RM, Pelosi P. CPAP devices for emergency prehospital use: a bench study. Respir Care 2015;60(12):1777-1785.

84. Chenelle CT, Oto J, Sulemanji D, Fisher DF, Kacmarek RM. Evaluation of an automated endotracheal tube cuff controller during simulated mechanical ventilation. Respir Care 2015;60(2):183-190.

85. Fisher DF, Kacmarek RM. Endotracheal tube holders and the prone position: a cause for concern-reply. Respir Care 2015;60(2):e42.

86. Kacmarek RM, Villar J, Blanch L. Why use anything but a standard spontaneous breathing trial to determine readiness for ventilator discontinuation? Respir Care 2015;60(11):1705-1707.

87. Saddawi-Konefka D, Hung SL, Kacmarek RM, Jiang Y. Optimizing mask ventilation: literature review and development of a conceptual framework. Respir Care 2015;60(12):1834-1840. 


\section{REMEMBERING RoBERT M. KACMAREK}

88. Vargas M, Servillo G, Pelosi P, Kacmarek RM. Are new devices for percutaneous dilatational tracheostomy really needed? Yes. Respir Care 2015;60(7):e133.

89. Vargas M, Servillo G, Tessitore G, Aloj F, Brunetti I, Arditi E, et al. Double lumen endotracheal tube for percutaneous tracheostomyreply. Respir Care 2015;60(3):e62-e63.

90. Ball L, Sutherasan Y, Caratto V, Sanguineti E, Marsili M, Raimondo $\mathrm{P}$, et al. Effects of nebulizer position, gas flow, and CPAP on aerosol bronchodilator delivery: an in vitro study. Respir Care 2016;61 (3):263-268.

91. Bell RC, Yager PH, Clark ME, Roumiantsev S, Venancio HL, Chipman DW, et al. Telemedicine versus face-to-face evaluations by respiratory therapists of mechanically ventilated neonates and children: a pilot study. Respir Care 2016;61(2):149-154

92. Branson RD, Kacmarek RM. Intermittent mandatory ventilation: what's in a name? Respir Care 2016;61(9):1282-1283.

93. Brusasco C, Corradi F, De Ferrari A, Ball L, Kacmarek RM, Pelosi P. CPAP devices for emergency prehospital use: looking inside of itreply. Respir Care 2016;61(5):719-720.

94. Imber DA, Pirrone M, Zhang C, Fisher DF, Kacmarek RM, Berra L. Respiratory management of perioperative obese patients. Respir Care 2016;61(12):1681-1692.

95. Kacmarek RM, Branson RD. Should intermittent mandatory ventilation be abolished? Respir Care 2016;61(6):854-866.

96. Mirelea-Cabodevila E, Kacmarek RM. We agree! Respir Care 2016;61(9):1280-1281

97. Mireles-Cabodevila E, Kacmarek RM. Should airway pressure release ventilation be the primary mode in ARDS? Respir Care 2016;61(6):761-773.

98. Pinciroli R, Mietto C, Piriyapatsom A, Chenelle CT, Thomas JG, Pirrone $\mathrm{M}$, et al. Endotracheal tubes cleaned with a novel mechanism for secretion removal: a randomized controlled clinical study. Respir Care 2016;61(11):1431-1439.

99. Walsh BK, Smallwood CD, Rettig JS, Thompson JE, Kacmarek RM, Arnold JH. Categorization in mechanically ventilated pediatric subjects: a proposed method to improve quality. Respir Care 2016;61 (9):1168-1178

100. Chenelle CT, Itagaki T, Fisher DF, Berra L, Kacmarek RM. Performance of the PneuX system: a bench study comparison with 4 other endotracheal tube cuffs. Respir Care 2017;62(1):102-112.

101. Itagaki T, Bennett DJ, Chenelle CT, Fisher DF, Kacmarek RM. Performance of leak compensation in all-age ICU ventilators during volume-targeted neonatal ventilation: a lung model study. Respir Care 2017;62(1):10-21.
102. Itagaki T, Chenelle CT, Bennett DJ, Fisher DF, Kacmarek RM. Effects of leak compensation on patient-ventilator synchrony during premature/neonatal invasive and noninvasive ventilation: a lung model study. Respir Care 2017;62(1):22-33.

103. Kacmarek RM, Walsh BK. The respiratory therapy profession is at a crossroads. Respir Care 2017;62(3):384-386.

104. Walsh BK, Smallwood C, Rettig J, Kacmarek RM, Thompson J, Arnold JH. Daily goals formulation and enhanced visualization of mechanical ventilation variance improves mechanical ventilation score. Respir Care 2017;62(3):268-278.

105. Bennett DJ, Carroll RW, Kacmarek RM. Evaluation of a low-cost bubble CPAP system designed for resource-limited settings. Respir Care 2018;63(4):395-403.

106. De Santis Santiago RR, Berra L, Kacmarek RM. Why not prevent ARDS? The possible role of plasma biomarkers in surgery. Respir Care 2018;63(11):1455-1456.

107. Kacmarek RM, Berra L, Villar J. On the road to surface monitoring of diaphragmatic activity in mechanically ventilated patients. Respir Care 2018;63(11):1457-1458.

108. Ejiofor BD, Carroll RW, Bortcosh W, Kacmarek RM. PEEP Generated by high-flow nasal cannula in a pediatric model. Respir Care 2019;64(10):1240-1249.

109. Kacmarek RM. Noninvasive respiratory support for postextubation respiratory failure. Respir Care 2019;64(6):658-678.

110. Pirrone M, Imber DA, Marrazzo F, Pinciroli R, Zhang C, Bry L, et al. Silver-coated endotracheal tubes cleaned with a mechanism for secretion removal. Respir Care 2019;64(1):1-9.

111. Spina S, Capriles M, De Santis Santiago R, Florio G, Teggia-Droghi M, Grassi L, et al. Development of a lung rescue team to improve care of subjects with refractory acute respiratory failure. Respir Care 2020;65(4):420-426.

112. Fernandes ND, Chung E, Salt MD, Ejiofor B, Carroll RW, Kacmarek RM. Measured CPAP in a noninvasive pediatric airway and lung model. Respir Care 2021;66(1):87-94.

113. Kacmarek RM, Berra L, Villar J. Consequences to the lungs when gas swings between lung units during patient triggered mechanical ventilation. Respir Care 2021;66(1):170-172.

114. Pierson DJ. The Respiratory Care journal conferences: 20 years of excellence and innovation. Respir Care 2002;47(3):238-246.

115. Hess DR, Branson RD, Moore S, Masferrer R. Reflections on the Respiratory CARE Open Forum. Respir Care 2018;63(10):13111313. 